\title{
Evaluation of generative accomplishment of new apple cultivars in Hungary
}

\author{
Csihon, Á., Holb, I.J. \& Gonda, I. \\ University of Debrecen, Faculty of the Agricultural and Food Sciences and Environmental Management, \\ Institute of Horticulture 138. Böszörményi str., Debrecen, H-4032, Hungary
}

\begin{abstract}
Summary: In a two year study, 14 new apple cultivars (cvs 'Gala Venus Fengal', 'Gala Decarli-Fendeca', 'Galaval', 'Jugala', 'Gala Schnitzer (S) Schniga', 'Red Cap Valtod (S)', 'Early Red One', 'Jeromine', 'Crimson Crisp (Co-op 39)', 'Red Topaz', 'Wilton's Red Jonaprince', 'Red Idared', 'Fuji September Wonder' and club cultivar) were studied in Eastern Hungary at Nyírbátor. The following parameters were measured: trunk cross sectional area $(\mathrm{cm} 2)$, harvest time with yield (date, $\mathrm{kg} /$ tree, number/tree), fruit size (mm), fruit surface color (\%), and color intensity of the fruit surface (1-5). According to our two year assessments regarding, the best generative accomplishment was achieved for the cvs 'Gala' sorts trained to slender spindle and the cv 'Red Jonaprince' trained to super spindle. According to the trunk cross sectional area the 'Gala' sport trained to slender spindle showed the strongest growth among the 4 years old trees, while the cv 'Fuji SW' and the cv 'Jeromine' presented lower vegetative accomplishment. The ripening time of the cultivars started at the end of August and finished at the beginning of October. 'Gala' mutants trained to slender spindle provided the highest yields. Fruit size of all cultivars reached the market required standard, however, cvs 'Red Jonaprince' and 'Red Idared' produced large fruits over $90 \mathrm{~mm}$. The fruit size of the 'Gala' sort was 72-75 mm. Most of the cultivars showed high fruit surface color and color intensity.
\end{abstract}

Keywords: apple cultivars, adaptability, yield, fruit surface color

\section{Introduction}

The apple is the most cultivated fruit in Hungary, means the $2 / 3$ part of the overall fruit production. In the last years the cultivated area decreased permanently. In 2000 the domestic apple production covered 41000 hectares, but nowadays the size of this area is about 25000 hectares $(K S H, 2013)$. In the short term it is a real threat that this reduction will continue up to 10-15 000 hectare, namely the tendency of the elimination of the out-of-date orchards is more intensive then the planting of the new plantations (Gonda \& Apáti, 2011, 2013).

The Hungarian apple production struggling with many problems, which can be concluded the next way based on studies of Gonda (2007) and Gonda \& Apáti (2011, 2013): i) significant part of the orchards are obsolete, at least 15000 hectares must be replanted, ii) the producers are polarized; there are just few farmers with sufficient fund and good infrastructure, on the other hand there are many farmers with scattered orchards, iii) there is not cooperation among the producers, while the traders are characterized by close cooperation, iv) lobbyist activity of the professional organizations is low, their potential is very limited, v) the research institutions can not function adequately, and vi) the yield safety is decreased significantly in the last years thanks to the global climate changing.

In addition to the above difficulties the cultivar assortment must be mentioned separately. Szabó et al. (2006) reported that a fast and powerful renewal is required in the domestic cultivar assortment. The produced cultivars are outdated, although the importance of the introduction of the new cultivars was emphasized for a long time by the domestic examinations. According to the KSH (2013) data, the most cultivated cultivar is the cv 'Idared' (23\%), while the dominating cultivar of the last decades, the cv 'Jonathan' still has $16 \%$. After that follows the cv 'Jonagold' (5.7\%), the cv 'Golden Reinders' (4.6\%) and the cv 'Starking Delicious' (3.7\%). However the cv 'Gala', which is one of the most popular cultivar of the European market currently, just produced on less then $1 \%$ of the apple growing areas.

Gonda (2007) claims that the excepted increase of the consumer demand requires also in our country the examination of the new foreign origin cultivars and the broadening of the cultivar assortment. Szabó et al. (2006) pointed out that the development of the cultivar assortment just can be successful if we start to produce outstanding cultivars which adapt adequately to our climatic conditions. According to Soltész \& Szabó stated that (1998) we have to follow the cultivar trends in the international production and in the same time based on this we have to select the cultivars which have the best adaptability under our climate circumstances. They emphasize also the necessity of the establishment of the different cultivar regions. It shouldn't be ignored that the ecological conditions are diverse in WesternHungary near to feet of the Alps and in the eastern part of the country, where the weather is more arid. It is necessary to pay more attention to this fact when we intend to plant a new cultivar, particularly in the case of the world cultivars 
which were born under different climate. In Europe some good examples can be found (Italy, France) where cultivar recommendations are available for the different production sites. The elaboration of a similar system is essential also in Hungary. In addition Soltész (1997) emphasize that the testing of the cultivars must be performed under as many diverse type of ecological conditions as possible. Some of the related results were published previously (Csihon et al., 2013; Csihon, 2014).

The aim of this study was determine the generative accomplishment of 14 new apple cultivars in Eastern fruit growing region of Hungary.

\section{Materials and methods}

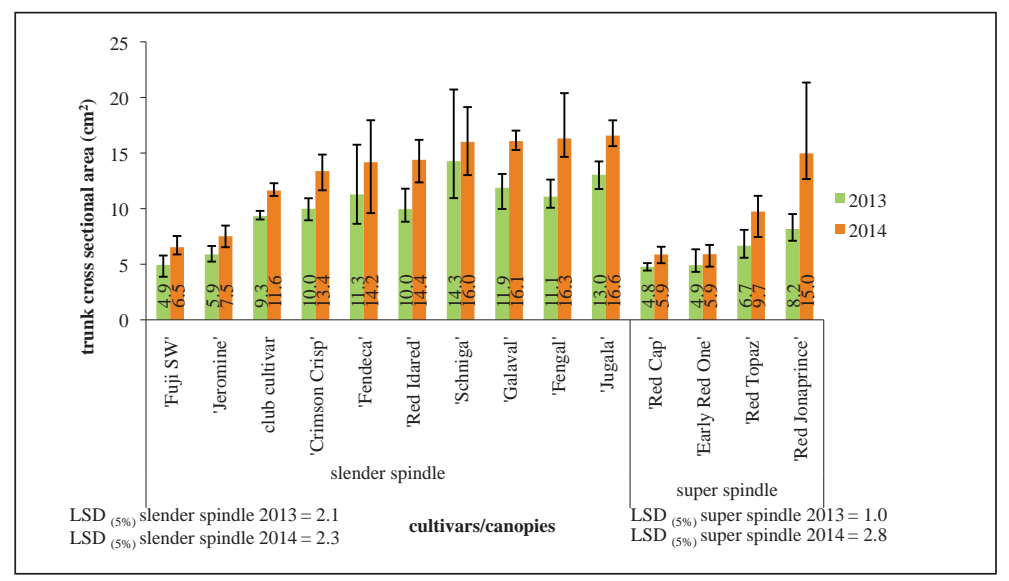

Figure 1: Trunk cross sectional area of the apple cultivars $\left(\mathrm{cm}^{2}\right)$ (Nyírbátor, 2013 and 2014).

This two year study was performed in 2013 and 2014, in the eastern part of Hungary, near to the village of Nyírbátor. The main parameters of the experimental area are the following: i) mean temperature of the year: $10-11^{\circ} \mathrm{C}$, ii) sunshine hours: 1900-2050 hours/year, iii) average precipitation in the last 10 years: $404 \mathrm{~mm}$, iv) soil pH: 6.92, v) humus content: low $(1 \%)$, the type of the soil is light sandy, and vi) the „Arany” number of heaviness: 27-29.

The most part of the cultivars were planted in 2011 spring, the smaller part were planted in 2010 autumn. The distance between the rows is $3.85 \mathrm{~m}$. Within row distance had two options: $1 \mathrm{~m}$ for slender spindle and $0.5 \mathrm{~m}$ for super spindle crown type. The rootstock of all scions was M9. The detailed planting design is shown in the Table 1 .

Table 1: The planting design of the 14 evaluated apple cultivars

\begin{tabular}{|l|c|c|c|}
\hline & $\begin{array}{c}\text { Year of } \\
\text { planting }\end{array}$ & Spacing & Canopy \\
\hline 'Gala Venus Fengal' & 2011 spring & $3.85 \mathrm{~m} \times 1 \mathrm{~m}$ & slender spindle \\
\hline $\begin{array}{l}\text { 'Gala Decarli- } \\
\text { Fendeca' }\end{array}$ & 2011 spring & $3.85 \mathrm{~m} \times 1 \mathrm{~m}$ & slender spindle \\
\hline 'Galaval' & 2011 spring & $3.85 \mathrm{~m} \times 1 \mathrm{~m}$ & slender spindle \\
\hline 'Jugala' & 2011 spring & $3.85 \mathrm{~m} \times 1 \mathrm{~m}$ & slender spindle \\
\hline $\begin{array}{l}\text { 'Gala Schnitzer (S) } \\
\text { Schniga' }\end{array}$ & 2010 autumn & $3.85 \mathrm{~m} \times 1 \mathrm{~m}$ & slender spindle \\
\hline 'Red Cap Valtod (S)' & 2011 spring & $3.85 \mathrm{~m} \times 0.5 \mathrm{~m}$ & super spindle \\
\hline 'Early Red One' & 2011 spring & $3.85 \mathrm{~m} \times 0.5 \mathrm{~m}$ & super spindle \\
\hline 'Jeromine' & 2010 autumn & $3.85 \mathrm{~m} \times 1 \mathrm{~m}$ & slender spindle \\
\hline 'Crimson Crisp' & 2011 spring & $3.85 \mathrm{~m} \times 1 \mathrm{~m}$ & slender spindle \\
\hline 'Red Topaz' & 2011 spring & $3.85 \mathrm{~m} \times 0.5 \mathrm{~m}$ & super spindle \\
\hline $\begin{array}{l}\text { 'Wilton's Red } \\
\text { Jonaprince' }\end{array}$ & 2011 spring & $3.85 \mathrm{~m} \times 0.5 \mathrm{~m}$ & super spindle \\
\hline 'Red Idared' & 2010 autumn & $3.85 \mathrm{~m} \times 1 \mathrm{~m}$ & slender spindle \\
\hline $\begin{array}{l}\text { 'Fuji September } \\
\text { Wonder' }\end{array}$ & 2011 spring & $3.85 \mathrm{~m} \times 1 \mathrm{~m}$ & slender spindle \\
\hline club cultivar & 2010 autumn & $3.85 \mathrm{~m} \times 1 \mathrm{~m}$ & slender spindle \\
\hline
\end{tabular}

In the orchard the trees are fixed to trellis system, the water supply is solved with dropping irrigation system. The plant protection is carried in accordance with the integrated management principles. It is important to notice that in the experimental plantation in the middle of March in 2013 heavy cold temperature occurred $\left(-17.6{ }^{\circ} \mathrm{C}\right)$, therefore fruit thinning intervention was not performed. The total yield of the cultivars under this circumstances shows their frost tolerance well. In 2014 the weather was exempt from extreme cold temperatures, so the crop load was controlled by chemical and additional hand thinning. In the orchard just 20 trees were planted for each cultivars.

To describe the characteristics of the cultivars 7 trees for each cultivars were used. In this study the following parameters were measured: trunk cross sectional area $\left(\mathrm{cm}^{2}\right)$, harvest time with yield (date, $\mathrm{kg} /$ tree, number/tree), fruit size $(\mathrm{mm})$, fruit surface color $(\%)$, and color intensity of the fruit surface (1-5).

\section{Results}

Cultivars of the 'Gala' sort (cvs 'Jugala', 'Fengal', 'Galaval', 'Schniga' and 'Fendeca') trained to slender spindle reached the highest trunk thickness at the end of 2014 (Figure 1). The cv 'Red Idared' showed also similar high value. Among the other cultivars the cv 'Fuji SW' and the cr 'Jeromine' showed significant weaker vegetative growth. The cvs 'Red Cap' and 'Early Red One' trained to super spindle reached also low values. The cv 'Red Jonaprince' displayed similar thick trunk then the 'Gala' sort, despite the smaller planting distance and the stronger root competition.

The ripening time of the cultivars started at the end of August with the 'Gala' sport (cvs 'Fengal', 'Fendeca' 'Galaval', 'Jugala' and 'Schniga'). We observed 6-8 days differences between the earliest and latest ripening 'Gala' cultivars (Table 2). The harvest time of the cv 'Jugala' shows large differences in the two years. This is due to the fact that in 2013 the harvest was performed too late, in overripe condition, namely the expected high fruit surface color and 


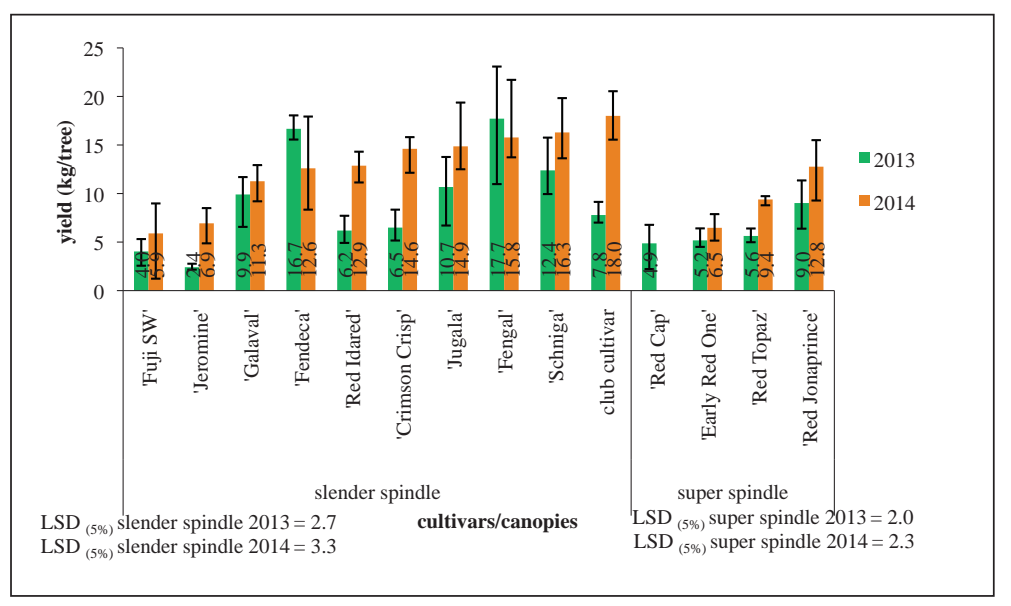

Figure 2: Yields (kg/tree) of 14 apple cultivars (Nyírbátor, 2013 and 2014).
Most of the cultivars reached higher values in 2014 compared to 2013 (Figure 2). Two cv 'Gala' mutants, the cvs 'Fengal' and 'Fendeca' produced outstanding yields $(17-18 \mathrm{~kg} / \mathrm{tree})$ on the three years old trees in 2013. Therefore thanks to the more moderate flower bud load of the next year they showed lower yields in 2014. Nevertheless among the cultivars trained to slender spindle these two cultivars and the cv 'Schniga' can be described with high values in both years $(12-18 \mathrm{~kg} / \mathrm{tree}$, and 13-16 kg/tree). Compared to the other cultivars the cv 'Fuji SW' and the cv 'Jeromine' produced lower yields. It is related with the trunk cross sectional area, namely that two cultivar showed the weakest vegetative accomplishment.

color intensity were not occurred. Accordingly the fruit with optimal starch quantity displayed low coloration and color intensity. In 2014 the fruits were picked in optimal biological maturity. The coloration of the fruits this time was also insufficient similarly to the previous year. Based on the foreign studies the main value of the cultivar is the early ripening time and good coloration. According to our examinations these benefits can not prevail in our experimental area.

Concerning the other cultivars the 'Red Delicious' sport (cvs 'Early Red One', 'Red Cap' and 'Jeromine'), the cv 'Fuji SW', the cv 'Crimson Crisp' and the cv 'Red Jonaprince' were harvested in the middle of September. The cv 'Red Idared', the cv 'Red Topaz' and the club cultivar were picked

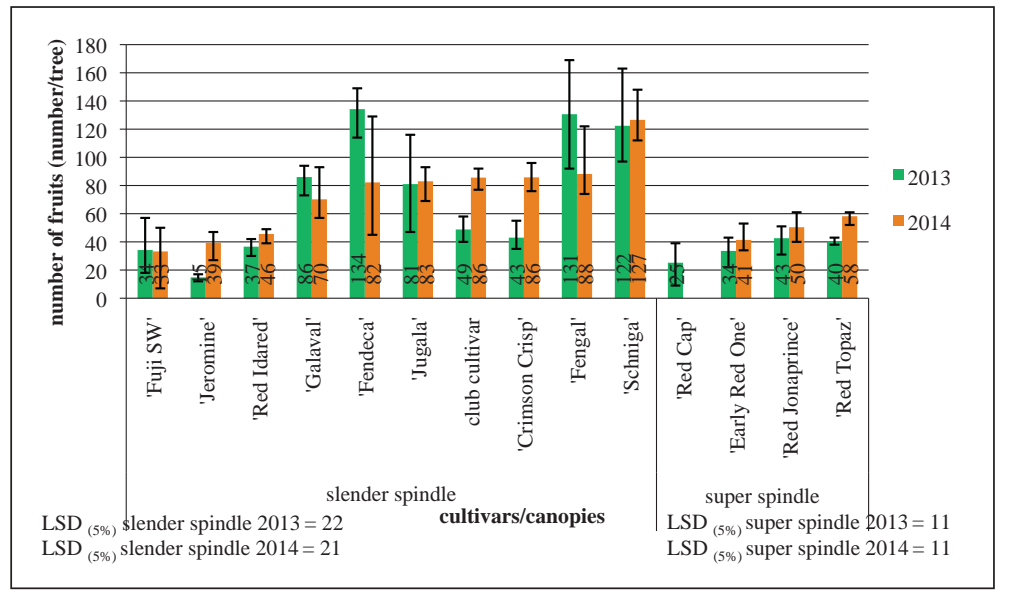

Figure 3: Fruit number per tree (Nyírbátor, 2013 and 2014). at the end of September. All of the cultivars were harvested with one pick except for the cv 'Schniga'. This cultivar showed slow and heterogeneous coloration, thus two picks were necessary to carry out.

Table 2: The harvest time (day/month) of the 14 apple cultivars (Nyírbátor, 2013 and 2014)

\begin{tabular}{|l|c|c|}
\hline & 2013 & 2014 \\
\hline 'Fengal' & $27 / 08$ & $26 / 08$ \\
\hline 'Fendeca' & $27 / 08$ & $26 / 08$ \\
\hline 'Galaval' & $30 / 08$ & $24 / 08$ \\
\hline 'Jugala' & $03 / 09$ & $24 / 08$ \\
\hline 'Schniga' & $03 / 09$ & $29 / 08$ \\
\hline 'Early Red One' & $13 / 09$ & $17 / 09$ \\
\hline 'Red Cap' & $15 / 09$ & - \\
\hline 'Jeromine' & $13 / 09$ & $17 / 09$ \\
\hline 'Fuji SW' & $19 / 09$ & $11 / 09$ \\
\hline 'Red Jonaprince' & $13 / 03$ & $17 / 09$ \\
\hline club cultivar & $30 / 09$ & $25 / 09$ \\
\hline 'Red Idared' & $30 / 09$ & $03 / 10$ \\
\hline 'Crimson Crisp' & $12 / 09$ & $11 / 09$ \\
\hline 'Red Topaz' & $30 / 09$ & $28 / 09$ \\
\hline
\end{tabular}

The 9-13 kg/tree yield of the cv 'Red Jonaprince' trained to super spindle can be considered as an excellent result. This amount is similar with the medium yield of a cultivar with slender spindle canopy.

Fruit number is reasonably strongly related with the yields of the trees (Figure 3). In both years the most fruits were harvested from the trees of the cv 'Schniga', the cv 'Fengal' and the cv 'Fendeca' (122-127 number/tree). The cv 'Fuji SW' and the cv 'Jeromine' showed the lowest values (15-39 number/tree). Notable different can be observed in the case of the cv 'Red Jonaprince'. As we have seen this cultivar reached high yields per tree, but the fruit number of the trees are much more lower. This is due to the larger fruit size.

Regarding with the training systems it can be stated, that the higher fruit number of the slender spindles canopies is well visible (120-130 number/tree), but a cultivar with weaker growth trained to slender spindle (cvs 'Fuji SW and 'Jeromine') can be described with a similar lower value than a cultivar trained to super spindle (40-50 number/ tree). It shows, that in terms of the fruit number per tree the characteristics of the cultivar are more dominant then the differences of the training systems.

In the case of the fruit numbers/tree it can not be seen such an evident different between the two years then in the yields/ 
tree. This is also due to the diverse fruit thinning practice of the two years. In 2013 spring, when heavy cold temperature occurred in the orchard fruit thinning was not performed. It resulted higher crop load then the optimal in the case of some cultivars (cvs 'Fengal' and 'Fendeca'). In 2014 the crop load approached the optimal value, when chemical and additional hand thinning were also fulfilled.

In term of the fruit size (Figure 4) the result of the different crop load of the years is well visible. In 2013 the fruits naturally were smaller $(66-85 \mathrm{~mm})$. The 'Gala' mutants reached 66-69 mm, the cv 'Red Idared', the cv 'Red Jonaprince' and the cv 'Red Cap' showed 81-85 mm. In 2014 every cultivars presented larger fruits, except for the cv 'Schniga'. This year the 'Gala' mutants showed also excellent fruit size $(72-75 \mathrm{~mm})$.

The $\mathrm{cv}$ 'Red Jonaprince' and the cv 'Red Idared' reached outstanding values in both years. In the case of the latter cultivar the diameter above $90 \mathrm{~mm}$ can be considered excessive, which could have negative effects (packing, storage).

The data of the fruit surface color (Figure 5) shows that the majority of the cultivars can be described with excellent values. In the most part of the cultivars between the two years the better coloration was measured in 2014.

The members of the 'Red Delicious' sport, the cvs 'Jeromine' and 'Early Red One' is practically covered $100 \%$ with surface color in 2014. Among the 'Gala' mutants the cvs 'Fendeca' and 'Galaval' showed $85-90 \%$, the cv 'Fengal' $80-90 \%$ coloration in the observed years. The cv 'Jugala' (70-75\%) and the cv 'Schniga' (40-70\%) presented lower values.

The coloration of the $\mathrm{cv}$ 'Red Idared' and the cv 'Red Topaz' is better (75-85\%) then the origin cultivar, like their names refers to it. The cv 'Crimson Crisp' showed also high fruit surface color (70-85\%) compared with other resistant cultivars. The cv 'Fuji SW' however presented low, $45-75 \%$ coloration.

Regarding the color intensity of the fruit surface (Figure 6), which means the darkness of the color, most of the cultivars (cvs 'Fengal', 'Fendeca', 'Galaval', 'Jeromine', 'Red Topaz', 'Early Red One', 'Crimson Crisp' and 'Red Jonaprince') reached the maximal values or close to it in both years. The cv 'Jugala', the cv 'Red Idared' and the club cultivar presented good color intensity in 2013, and excellent color intensity in 2014. The cv 'Schniga' and the cv 'Fuji SW' can be described with lower values in both years.

In summary, the best generative accomplishment was achieved for the cvs 'Gala' sorts trained to slender spindle and the cv 'Red Jonaprince' trained to super spindle. According to the trunk cross sectional area the 'Gala' sport trained to slender

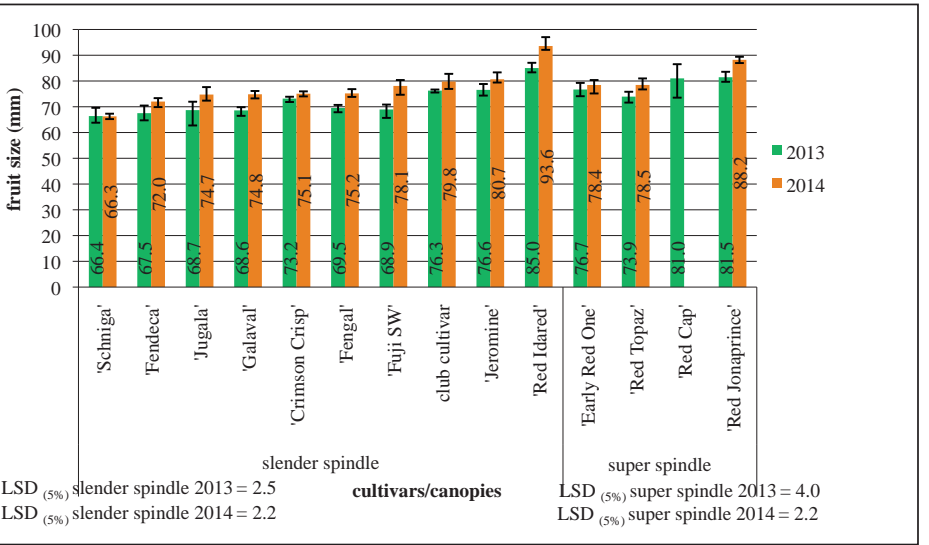

Figure 4: Fruit size of the cultivars (Nyírbátor, 2013-2014)

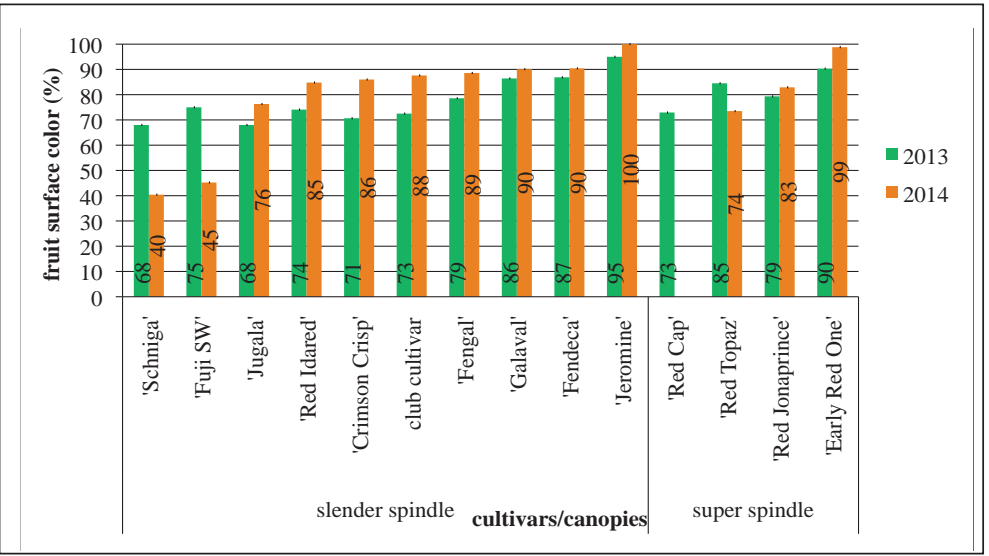

Figure 5: Fruit surface color of the cultivars (Nyírbátor, 2013 and 2014)

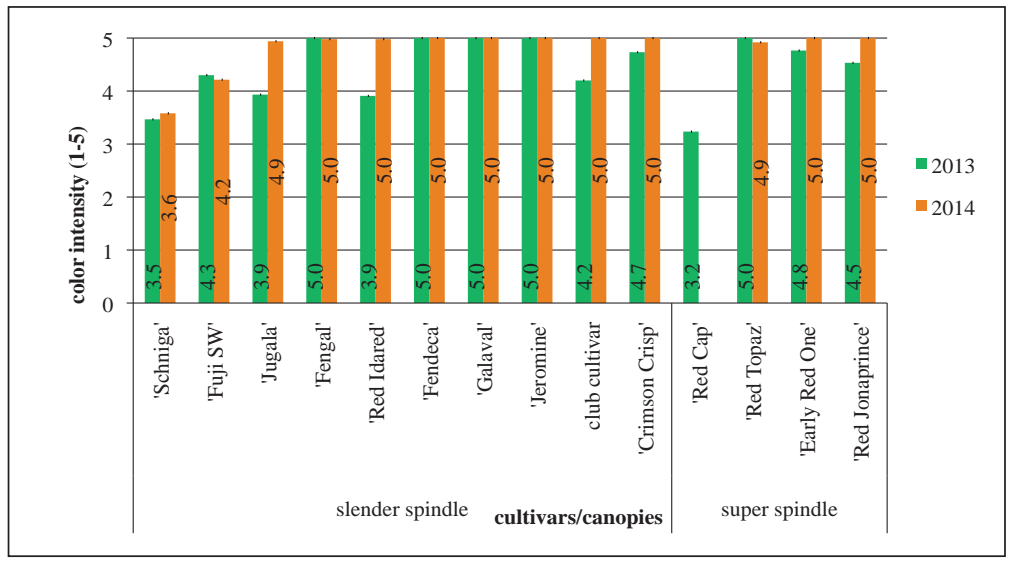

Figure 6: Color intensity of the fruit surface (Nyírbátor, 2013 and 2014)

spindle showed the strongest growth among the 4 years old trees, while the cv 'Fuji SW' and the cv 'Jeromine' presented lower vegetative accomplishment. The ripening time of the cultivars started at the end of August and finished at the beginning of October. 'Gala' mutants trained to slender spindle provided the highest yields. Fruit size of all cultivars reached the market required standard, however, cvs 'Red Jonaprince' and 'Red Idared' produced large fruits over $90 \mathrm{~mm}$. The fruit size of the 'Gala' sort was $72-75 \mathrm{~mm}$. Most of the cultivars showed high fruit surface color and color intensity. 


\section{Acknowledgements}

This research was supported by grants of the Hungarian Scientific Research Fund (K108333).

\section{References}

Csihon, Á. (2014): Evaluation of the vegetative and generative performance of new apple cultivars in the Nyírség region. International Journal of Horticultural Sciences 20 (3-4): 39-44.

Csihon, Á., Holb, I. \& Gonda, I. (2013): The relationship of the plant protection and the applied technology in the integrated apple production. International Journal of Horticultural Sciences 19 (3-4): 11-14.

Gonda, I. (2007): Magyar alma: Tovább a lejtőn?! Az almatermesztés helyzete és változásának tendenciái. [In: Ágazatspecifikus innováción alapuló projektek generálása az alma ágazatban. Szerk.: Felföldi, J.] Szaktanácsadási Füzetek 15. Debreceni Egyetem. 44-47.
Gonda, I., Apáti, F. (2011): Almatermesztésünk helyzete és jövőbeni perspektívái. [In: Almaültetvények vízkészlet-gazdálkodása. Szerk.: Tamás, J.] Kiadja: DE AGTC Kutatási és Fejlesztési Intézet, Kecskeméti Főiskola, KFK. 13-25.

Gonda, I., Apáti, F. (2013): Az almatermesztésünk helyzete és kilátásai. [In. Almatermesztés új alapokon. Szerk.: Balogh, L.] Kiadó: Naturalma Zrt. 7-13.

KSH (2013): Alma-, körte-, kajszi- és őszibarackültetvények adatai, 2012.

Soltész, M. (1997): Gyümölcsösök létesítése. [In: Integrált gyümölcstermesztés. Szerk.: Soltész, M.] Mezőgazda Kiadó, Budapest. 200-226.

Soltész, M., Szabó, T. (1998): Alma. [In: Gyümölcsfajta-ismeret és -használat. Szerk.: Soltész, M.] Mezőgazda Kiadó, Budapest. $119-155$

Szabó, Z., Racskó, J., Nyéki J. (2006): Almaklubfajták itthon és a nagyvilágban. AgrárUnió 7 (10-11): 31-32. 